\title{
PETROLEUM SYSTEMS OF THE MALAY BASIN PROVINCE, MALAYSIA
}

by Michele G. Bishop ${ }^{1}$

Open-File Report 99-50T

2002

This report is preliminary and has not been reviewed for conformity with the U. S. Geological Survey editorial standards or with the North American Stratigraphic Code. Any use of trade names is for descriptive purposes only and does not imply endorsements by the U. S. government.

\section{U. S. Department of the Interior U. S. Geological Survey}

${ }^{1}$ Consultant, Wyoming PG-783, contracted to U. S. Geological Survey, Denver, Colorado 


\section{FOREWORD}

This report was prepared as part of the World Energy Project of the U.S. Geological Survey. For this project, the world was divided into 8 regions and 937 geologic provinces, which were then ranked according to the discovered oil and gas volumes within each (Klett and others, 1997, U. S. Geological Survey World Energy Assessment Team, 2000). Then, 76 "priority" provinces (exclusive of the U.S. and chosen for their high ranking) and 26 "boutique" provinces (exclusive of the U.S. and chosen for their anticipated petroleum richness or special regional economic importance) were selected for appraisal of oil and gas resources. The petroleum geology of these priority and boutique provinces is described in this series of reports.

The purpose of the World Energy Project is to assess the quantities of oil, gas, and natural gas liquids that have the potential to be added to reserves within the next 30 years. These volumes either reside in undiscovered fields whose sizes exceed the stated minimumfield-size cutoff value for the assessment unit (variable, but must be at least 1 million barrels of oil equivalent) or occur as reserve growth of fields already discovered.

The total petroleum system constitutes the basic geologic unit of the oil and gas assessment. The total petroleum system includes all genetically related petroleum that occurs in shows and accumulations (discovered and undiscovered) that (1) has been generated by a pod or by closely related pods of mature source rock, and (2) exists within a limited mappable geologic space, along with the other essential mappable geologic 
elements (reservoir, seal, and overburden rocks) that control the fundamental processes of generation, expulsion, migration, entrapment, and preservation of petroleum. The minimum petroleum system is that part of a total petroleum system encompassing discovered shows and accumulations along with the geologic space in which the various essential elements have been proved by these discoveries.

An assessment unit is a mappable part of a total petroleum system in which discovered and undiscovered fields constitute a single relatively homogenous population such that the chosen methodology of resource assessment based on estimation of the number and sizes of undiscovered fields is applicable. A total petroleum system might equate to a single assessment unit, or it may be subdivided into two or more assessment units if each assessment unit is sufficiently homogeneous in terms of geology, exploration considerations, and risk to assess individually.

A graphical depiction of the elements of a total petroleum system is provided in the form of an event chart that shows the times of (1) deposition of essential rock units; (2) trap formation; (3) generation, migration, and accumulation of hydrocarbons; and (4) preservation of hydrocarbons.

A numeric code identifies each region, province, total petroleum system, and assessment unit; these codes are uniform throughout the project and will identify the same type of entity in any of the publications. The code is as follows: 


\section{Example}

Region, single digit 3

Province, three digits to the right of region code 3162

Total Petroleum System, two digits to the right of province code 316205 Assessment unit, two digits to the right of petroleum system code 31620504

The codes for the regions and provinces are listed in Klett and others, 1997 and U. S. Geological Survey World Energy Assessment Team, 2000

Oil and gas reserves quoted in this report are derived from Petroconsultants' Petroleum Exploration and Production database (Petroconsultants, 1996) and other area reports from Petroconsultants, Inc., unless otherwise noted.

Fields, for the purpose of this report, include producing fields, discoveries (suspended and abandoned) and shows as defined by Petroconsultants (1996) and may consist of a single well with no production.

Figure(s) in this report that show boundaries of the total petroleum system(s), assessment units, and pods of active source rocks were compiled using geographic information system (GIS) software. Political boundaries and cartographic representations were taken, with permission, from Environmental Systems Research Institute's ArcWorld 1:3 million digital coverage (1992), have no political significance, and are displayed for general reference only. Oil and gas field centerpoints, shown on this (these) figure(s), are 
reproduced, with permission, from Petroconsultants, 1996.

\section{REFERENCES}

Environmental Systems Research Institute Inc., 1992, ArcWorld 1:3M digital database: Environmental Systems Research Institute, Inc. (ESRI), available from ESRI, Redlands, CA, scale: 1:3,000,000.

Klett, T.R., Ahlbrandt, T. A., Schmoker, J.W., and Dolton, G. L., 1997, Ranking of the world's oil and gas provinces by known petroleum volumes: U.S. Geological Survey Open-File Report 97-463, one CD-ROM.

Petroconsultants, 1996, Petroleum Exploration and Production Database:

Petroconsultants, Inc., P.O. Box 740619, 6600 Sands Point Drive, Houston TX 77274-0619, USA or Petroconsultants, Inc., P.O. Box 152, 24 Chemin de la Mairie, 1258 Perly, Geneva, Switzerland.

U. S. Geological Survey World Energy Assessment Team, 2000, U. S. Geological Survey World Energy Petroleum Assessment 2000-Description and Results: USGS Digital Data Series DDS-60, four CD-ROMs. 


\begin{abstract}
The offshore Malay Basin province is a Tertiary oil and gas province composed of a complex of half grabens that were filled by lacustrine shales and continental clastics. These deposits were overlain by clastics of a large delta system that covered the basin. Delta progradation was interupted by transgressions of the South China Sea to the southeast, which finally flooded the basin to form the Gulf of Thailand. Oil and gas from the Oligocene to Miocene lacustrine shales and Miocene deltaic coals is trapped primarily in anticlines formed by inversion of the half grabens during the late Miocene.

Hydrocarbon reserves that have been discovered amount to 12 billion barrels of oil equivalent. The U.S. Geological Survey assessment of the estimated quantities of conventional oil, gas and condensate that have the potential to be added to reserves by the year 2025 for this province is 6.3 billion barrels of oil equivalent (BBOE) (U. S.

Geological Survey World Energy Assessment Team, 2000).

\section{INTRODUCTION}

The Malay Basin Province (3703) consists of Tertiary transtensional extensional basins with at least two total petroleum systems: the Oligocene-Miocene Lacustrine Total Petroleum System (TPS)(370301) with lacustrine shale source and reservoir rocks (divided into two assessment units, South Malay Lacustrine assessment unit (AU)(37030101) and North Malay Lacustrine assessment unit (37030102)); and the Miocene-Coaly Strata Total Petroleum System (370302) with coal and coaly shale source and fluvial, deltaic, nearshore marine and offshore marine bar reservoirs (one assessment unit South Malay Coaly AU (37030201)). Source rocks began generating hydrocarbons in the middle Miocene at approximately 1,000 to 3,500 $\mathrm{m}$ burial depth. All potential 
source rocks are over-mature in the center of the basin and under-mature at the edges.

Hydrocarbons are trapped in Middle to Late Miocene transpressional folds, drape anticlines, and some stratigraphic traps.

The U.S. Geological Survey assessment at the meanof the estimated quantities of conventional oil, gas and condensate that have the potential to be added to reserves by the year 2025 for this province is 1 billion barrels of oil (BBO), 21.9 trillion cubic feet of gas (TCFG), and 410 million barrels of natural gas liquids (BBNGL) for the South Malay Lacustrine AU; 124 MMBO, 1.8 TCFG, and 32 MMBNGL for the North Malay Lacustrine AU; and 101 MMBO, 3.77 TCFG, and 72 MMBNGL for the South Malay Coaly AU (U.S.Geological Survey World Energy Assessment Team, 2000).

\section{PROVINCE GEOLOGY}

The Malay Basin Province (Fig. 1) is entirely offshore and is composed of the Malay Basin (primarily in the waters of Malaysia, with smaller portions in the waters of Thailand, Indonesia and Vietnam) and the Khmer Trough (in Cambodian waters). This province is north of the Malaysian Peninsula, south of Cambodia and Vietnam and straddles the Gulf of Thailand and the South China Sea. Water depth is less than $200 \mathrm{~m}$. The province has produced more than 1.6 billion barrels of oil equivalent hydrocarbon (BBOE) and has the potential for recovery of known reserves of more than $12 \mathrm{BBOE}$ (Petroconsultants, 1996).

The Malay Basin is approximately $83,000 \mathrm{~km}^{2}$. The basin is approximately 500 $\mathrm{km}$ long and $200 \mathrm{~km}$ wide. Robinson (1985) estimated the volume of Tertiary sediments in the Malaysian portion of the basin at $338,000 \mathrm{~km}^{3}$ with more than $9,150 \mathrm{~m}$ of Tertiary 
sediments in some areas. However, more recent estimates suggest that more than $12 \mathrm{~km}$ of Oligocene and post-Oligocene sediments have filled the basin (Tjia, 1994; Ngah and others, 1996). The Malay Basin trends northwest to southeast running almost perpendicular to the east/west trending Penyu Basin and the northeast/southwest trending West Natuna basins on its south and bends north/south at its northern end to parallel the Pattani Basin in the Gulf of Thailand (Hutchison, 1996).

Basement rock rises to the northeast from greater than $12,000 \mathrm{~m}$ to less than 3,000 m depth toward Vietnam and southwest across the Western Hingline Fault to Peninsular Malaysia (Fig. 2). The Western Hingeline fault zone marks the southwest margin of the basin, although the Dungun fault zone, a fault splay, forms a deep half graben further to the southwest (Ngah and others, 1996). The Tenggol Arch separates the Malay Basin from the Penyu Basin to the south and the Narathiwat High protrudes from Peninsular Malaysia between the Pattani Basin and the Malay Basin (Fig. 2) (Ngah and others, 1996). Basement rock is described from the southwestern margin of the basin as PermoCarboniferous metasediments and volcanics, Cretaceous granites, and possible Cretaceous rift-fill (Liew Kit Kong, 1994). In the northwest the basement consists of Mesozoic to Carboniferous carbonates and Mesozoic granites (Leo, 1997).

The Khmer Trough or basin is a Tertiary half-graben rift basin located in the eastern Gulf of Thailand and at the northern extension of the Malay Basin Province (3703) (Fig. 2). This half-graben is $150 \mathrm{~km}$ long and $60 \mathrm{~km}$ wide, trends north/south, and is bounded on the east by a west-dipping bounding fault. Tertiary sediments in the Khmer Trough are up to 8,000 m thick (Akihiko and others, 1997). This half-graben is 
separated from the Pattani Trough in the Gulf of Thailand by the Khmer Ridge, the shoaling side of this half-graben.

Exploration History

In 1910, a discovery onshore initiated exploration efforts in Malaysia; offshore exploration started in 1957 (Ahmad Said, 1982). Offshore discoveries, to date, have included gas in the Thai and northwest Malaysian part of the Malay Basin and oil and gas in the central and southern areas. The deepest well listed by Petroconsultants (1996) in the province is in the Tabu field at 4,735 $\mathrm{m}$ (Fig. 1).

In 1969 ESSO began drilling in the Malay Basin and by 1975 significant quantities of oil and gas had been discovered in the Seligi, Pulai, Tapis and Bekok formations of Oligocene to Early Miocene age. The earliest oil was discovered in the Seligi, Tapis, Pulai and Bekok fields and gas in the Angsi, Besar and Belumut fields (Fig. 1) (Ahmad Said, 1982).

Drilling began in the Thai portion of the Gulf in 1971 and Bongkot was discovered in 1973 by Texas Pacific, who drilled 23 wells (Fig. 1) (Leo, 1997). Bongkot passed through the hands of the National Exploration and Production Oil Company of Thailand (PTTEP), to the partnership of Total, Statoil, British Gas, and PTTEP (Leo, 1997).

Drilling began in the Khmer Trough portion of the province in 1974 and possible economic discoveries were found in 1994 (Petroconsultants, 1996) (Fig. 1). Discoveries in this area are dominantly gas with some oil in Oligocene to Early Miocene deltaic sandstones in anticlinal traps (Petroconsultants, 1996). Apsara-1, drilled in 1994, was Cambodia's first discovery and the well flowed 300 to 400 barrels per day of oil and a 
small amount of gas (Oil and Gas Journal, 1998). Known estimated recoverable reserves in the Khmer Trough part of the province are from three discoveries and amount to 35 MMBOE (Petroconsultants, 1996).

Three major tectonic episodes contributed to the current petroleum province of the Malay Basin region; 1) upper Eocene to Oligocene extension with left-lateral shear and major subsidence, 2) middle to upper Miocene north to south compression with reverse or right-lateral shear, folding, and inversion, 3) Pliocene to Holocene minor extension and gentle subsidence (Hutchison, 1996; Ng, 1987; Ngah and others 1996).

Left-lateral shear during the late Eocene to Oligocene formed pull-apart basins and half grabens into which thick sedimentary sequences were deposited (Ngah and others 1996, and Tjia and Liew, 1996). Expulsion of portions of continental Southeast Asia resulted from collision between the India plate and the Eurasia plate in the midEocene (Tjia, 1994, and Ngah and others, 1996). This expulsion produced left-lateral shear on a southeastern extension of the Three Pagoda fault zone in the Malay Basin (a major fault system onshore Thailand) (Tjia, 1994; Ngah and others, 1996; Mazlan B. Hj. Madon, 1997).

During the Miocene, differential expulsion of Southeast Asia occurred, due to the combined effects of northward and westward convergence of the India, Australia and Pacific plates. This expulsion reversed the motion of the fault zone to right-lateral wrenching along the Axial Malay fault (Tjia and Liew, 1996; Tjia, 1994; Ngah and others, 1996; Mazlan B. Hj. Madon, 1997). The resulting compression and wrenching during the middle to late Miocene inverted the previous half-graben basins. The inversion increases from mildly inverted structures in the north to completely inverted 
half grabens in the southern part of the basin (Mazlan B. Hj. Madon, 1997). Inversion of the half grabens formed anticlinal folds. These folds trend east to west except in the southwest margin where the anticlines trend northwest to southeast and the northwest corner of the basin where the anticlines trend almost north to south (Ngah and others, 1996). The anticlines are oriented the same as the underlying half graben (Ngah and others, 1996; Tjia and Liew, 1996) and are located in the thickest sedimentary section of the half-grabens. Folding of half-graben sediments occurs without apparent faulting (Cooper and others, 1989). Wrench faulting occurred in the transpressive tectonic compressional episode. A period of erosion resulted in removal of perhaps 1,200 $\mathrm{m}$ of Miocene section, from the Malay Basin, prior to deposition of the overlying Pliocene sediments (Cooper and others, 1989).

Compressional folding ceased in the earliest Pliocene (Cooper and others, 1989). Gentle subsidence and regional deposition of flat-lying marine clastics has continued across most of the region since the Early Pliocene (Tjia, 1994). North striking normal faults perpendicular to the crests of the anticlines are the most recent tectonic element (Tjia, 1994).

Deformation during the Tertiary was influenced by pre-Cenozoic features. A preTertiary, possibly Late Cretaceous, dome more than $500 \mathrm{~km}$ wide centered at the triple junction of the Malay, Penyu, and West Natuna Basins was proposed by Ngah and others (1996). The particularly high heat flow at this junction may be due to an underlying mantle plume (Ngah and others, 1996). The structural grain of Cenozoic tectonics parallels the tectonic grain of Late Triassic to Early Jurassic structure from onshore evidence (Ngah and others, 1996). The north-northwest/northwest trends are parallel to 
the Sundaland and Sumatra trends and the north/south trends to those of onshore Thailand.

Stratigraphy

The oldest basinal sediments are thought to be early Oligocene continental alluvial clastics filling graben basins and topography (Fig. 3). The oldest grabens may contain late Eocene to early Oligocene sediments (Hutchison, 1996). Recent seismic data indicates several kilometers of sediments beneath the known upper Oligocene strata suggesting initiation of the basin well before the Oligocene (Hutchison, 1996).

Oligocene and lower Miocene reservoir rocks include coarse- to medium-grained fluvial and alluvial fan sandstones (Chu Yun Shing, 1992; Hutchison, 1996). Lacustrine shales accumulated in many of the isolated graben (Hutchison, 1996). The earliest sediments were derived locally from the margins of the half-graben basins. These lacustrine shales are interpreted to be the source rocks for oil, gas, and condensate in the Oligocene and lower Miocene reservoirs (Creaney and others, 1994; McCaffrey and others, 1998; Cole and Crittenden, 1997; Todd and others, 1997).

According to the stratigraphic divisions used by ARCO, rocks of the upper Oligocene to lower Miocene M, L, K, and J Groups, are non-marine in origin (Fig. 3) (Ngah and others, 1996, McCaffrey and others, 1998). Marine influences in the basin began during deposition of the I Group (Fig. 3) (Ngah and others, 1996, McCaffrey and others, 1998, and Tjia and Liew, 1996).

Marine influence increased during the Miocene as the South China Sea generally transgressed the region from southeast to northwest (Leo, 1997). Regional sources of clastics were located at topographic highs to the northwest, west and east. A major 
fluvial system entered the region from near the present location of Bangkok, Thailand, and is called the paleo-Chao Praya river system (Leo, 1997). The course of this paleoriver system flowed south during Oligocene and Miocene time, along the Pattani Trough and then southeast along the Malay Basin trend. It formed a large delta complex from about present day latitude $102^{\circ} \mathrm{E}$ to the shoreline of the contemporary South China Sea, approximately $106^{\circ} \mathrm{E}(\mathrm{Leo}, 1997)$. The delta front and shoreline were perpendicular to the trend of the Malay Basin so that the southern end of the basin might be receiving marine shoreline deposits contemporaneous with fluvial deposits at the northern end. Facies of the paleo-Chao Praya system comprise many of the reservoir rocks and coal and coaly shale source rocks.

In the middle to late Miocene, the West Natuna area was uplifted and became a major source of clastics transported northwest into the basin (Hutchison, 1996). The Khmer Trough remained in a continental fluvial depositional setting until the very late Miocene (Akihiko and others, 1997). Middle to upper Miocene rocks were deposited in deltaic to shallow marine settings and include coals and coaly shales. Tjia and Liew (1996) describe a maximum flooding surface (Fig. 3) that acts as a regional seal. Strata of the overlying middle Miocene H Group through upper Miocene D Group were deposited during alternating marine transgressions and regressions (Tjia and Liew, 1996). The transgressions formed several regional seals for the coal and coaly shale source rocks and reservoir rocks of this interval (McCaffrey and others, 1998). Non-deposition and erosion occurred at the southeast margin at Pulani-1, and to the north and southwest (Ngah and others, 1996). 
Generally transgressive deposits continued across most of the Malay Basin from late Miocene to Pleistocene (Tjia and Liew, 1996). Most of the province was exposed to erosion during the Pleistocene lowstands and channels were cut across the basin (Tjia, 1994).

\section{PETROLEUM OCCURRENCE}

There is spatial overlap between the Oligocene-Miocene Lacustrine TPS that has a lacustrine signature (370301) and the Miocene-Coaly Strata TPS that has a coaly signature (370302) (Fig. 4). In general, the Oligocene-Miocene Lacustrine TPS contains reservoirs older and deeper than the Miocene-Coaly Strata TPS. There are some oils in interval I (Fig. 3) that show both a coaly and lacustrine origin (McCaffrey and others, 1998). It is unclear with the data available if these reservoirs were filled by a mixture of oils that migrated vertically up from the Oligocene-Miocene Lacustrine TPS and vertically down from the Miocene-Coaly Strata TPS or if they were filled by oil derived from a mixed source rock within the I interval. For the purposes of this study these mixed reservoir oils are placed in the Oligocene-Miocene Laustrine TPS Oligocene-Miocene Laustrine TPS 370301

The majority of the oil and associated gas discoveries in the province are in the southeast and the majority of these belong to the South Malay Lacustrine AU. To the northwest, the AU has had mainly gas/condensate discoveries. To the far north of the province in the Khmer Trough, a few discoveries have recently been made of both oil and gas belonging to the North Malay Lacustrine AU. 
Of the volume of estimated recoverable oil equivalent reserves in the province, $52 \%$ are in the Oligocene-Miocene Lacustrine TPS (Petroconsultants, 1996). This system contains $68 \%$ of the oil reserves, $45 \%$ of the gas reserves, and $43 \%$ of the condensate reserves (Petroconsultants, 1996).

Miocene-Coaly Strata Total Petroleum System 370302

The transition area in the middle of the basin, stratigraphically overlying the Oligocene-Miocene system, contains discoveries of oil, gas and condensate that belong to the South Malay Coaly assessment unit. The cause of this oil and gas distribution pattern is not clear from the literature; fractionation during migration, individual lacustrine source rock basins with oil or gas prone source rocks, and differing burial history are possibilities.

Marine transgressions and regressions deposited rocks of the H, F, E, D, B, and A Groups (Fig. 3) (Ngah and others, 1996, McCaffrey and others, 1998, Tjia and Liew, 1996 and Tjia, 1994). These strata are source and reservoirs for the Miocene-Coaly Strata TPS.

More than $38 \%$ of the volume of estimated recoverable reserves are in the Miocene-Coaly Strata TPS, 7\% (Petroconsultants, 1996). This system contains $17 \%$ of the oil reserves, $47 \%$ of the gas reserves, and $53 \%$ of the condensate reserves in the province (Petroconsultants, 1996).

\section{SOURCE ROCKS}

Oligocene-Miocene Lacustrine Total Petroleum System 
Distinct lacustrine-sourced oils have been discussed by Creaney and others (1994) and McCaffrey and others, (1998) and might be expected from isolated rift lakes with different depositional histories. In the absence of detailed analyses, these lacustrine source rocks are combined into one total petroleum system for the purposes of this report. The lacustrine source rock quality is good, with total organic carbon (TOC) 1-4 wt $\%$ and hydrogen index (HI) as high 750, as measured from sidewall cores and cuttings (Creaney and others, 1994).

Geothermal gradients are reported to range from $6.3^{\circ} \mathrm{C} / 100 \mathrm{~m}$ in the northwest part of the province to $3.6^{\circ} \mathrm{C} / 100 \mathrm{~m}$ in the southern end of the basin (Robinson, 1985). An average geothermal gradient, calculated from more than 100 wells in the Malay Basin, was $51.8^{\circ} \mathrm{C} / \mathrm{km}$ (Mohd Firdaus Abdul Halim, 1994). Using the range of 45$52^{\circ} \mathrm{C} / \mathrm{km}$ - 1 the oil window would be between $1,000 \mathrm{~m}$ and $3,500 \mathrm{~m}$. This estimate places the Oligocene and Lower Miocene formations in the center of the basin in an over-mature position (Creaney and others, 1994).

The $\mathrm{CO}_{2}$ content in gas from the Thai ' $\mathrm{B}$ ' structure, near Bonkot field, increases with depth and averages $32 \%$ (Du Bois, 1980). The $\mathrm{CO}_{2}$ content reaches $70 \%$ in the Dulang Field and is high in other wells where deep faults act as a migration path for overmature source rocks and altered carbonate cement (personal communication Mark McCaffrey, 1999).

Creaney and others (1994) indicate lacustrine sources have low pristane-phytane ratios $(\mathrm{Pr} / \mathrm{Ph})$, a low oleanane content, absence of resin-derived terpane, TOCs of 1.0-4.0 wt\%, and HI up to 750. Creaney and others (1994) indicate that their studies show strata- 
parallel migration dominates and little cross-strata mixing occurs. Migration is primarily toward the northeast from the southwest portions of the Malay Basin.

In the Khmer Trough, migration occurs out of the lacustrine source rock area, vertically along faults, against the bounding fault, and along carrier beds. The hydrocarbons accumulate in fault, structural, and stratigraphic traps on the shoaling margin of the half graben similar to the Asri Basin offshore North West Java (Bishop 2000). Fluvial and lacustrine conditions prevailed in the isolated basin of the Khmer Trough, from the Oligocene to the Late Miocene, after which marine conditions existed in the entire gulf. There is $8,000 \mathrm{~m}$ of Tertiary sediments in the basin (Akihiko and others, 1997). The self-contained lacustrine nature of this basin produced high quality algal source rocks that are oil-prone with TOC up to $3 \mathrm{wt} \%$ and an HI of 500 mgHC/gTOC (milligrams of hydrocarbon per gram of total organic carbon) (Akihiko and others, 1997). The Middle and Upper Miocene fluvial deltaic shales and coals are also good oil-prone source rocks with TOC of $60 \mathrm{wt} \%$ and 100-400 mgHC/gTOC hydrogen index (Akihiko and others, 1997).

The upper Oligocene source rocks in the Khmer Trough began generating oil in late Miocene and the upper portion of the section remains in a late-stage of oil generation (Akihiko and others, 1997). The lower and lower upper Oligocene section has been generating gas since the Pliocene (Akihiko and others, 1997). Peak migration in the Khmer Trough occurred in the middle Miocene. The overlying Miocene oil-prone coals in this area are not in the oil window (Akihiko and others, 1997) but they have generated oil in the adjacent Pattani Trough to the west and in the Malay Basin. 


\section{Miocene-Coaly Strata Total Petroleum System}

The coal and coaly shale source rocks have $\mathrm{Pr} / \mathrm{Ph}$ up to 8 , high oleanane, and abundant resinous compounds (Creaney and others, 1994). These source rocks can be compared to the mangrove swamp deposits that are rich source rocks of paralic, delta plain, bay and esturine origins in other basins of Southeast Asia (Todd and others, 1997).

\section{TRAPS}

Mid- to late Miocene transpression created anticlines that are the most important hydrocarbon traps in the province. These anticlines occur parallel to the faulted half grabens and involve sediments deposited in the thickest portion of the half graben (Fig. 2) (Ngah and others, 1996, Tjia and Liew, 1996, Tjia, 1994). Anticlines account for 68\% of the discovered recoverable reserves in the province (Petroconsultants, 1996). Traps described as fault block and normal fault contain $29 \%$ of the discovered reserves (Petroconsultants, 1996). Approximately 58\% of the fields listed by Petroconsultants (1996) are described as anticlines with $38 \%$ of the total fields either fault block or normal fault traps.

Post-Miocene movement on north to south oriented faults (Tjia, 1994) could have created migration paths for mixing of oils of the Oligocene-Miocene Lacustrine TPS with oils of the Miocene-Coaly Strata TPS. This faulting could have breached Middle Miocene to Early Pliocene traps, where generation and migration began in Middle Miocene, and provided remigration routes for previously trapped hydrocarbons. 
Oligocene-Miocene Lacustrine Total Petroleum System

Trap type plays an important role in the volume and type of reserves that have been discovered in each petroleum system in the province. Approximately $48 \%$ of the volume of estimated reserves of recoverable oil equivalent that occur in anticline traps are found in the Oligocene-Miocene Lacustrine TPS, $64 \%$ of the fault-block and faulted traps, and $98 \%$ of the stratigraphic traps (Petroconsultants, 1996).

Miocene-Coaly Strata Total Petroleum System

pproximately $45 \%$ of the recoverable reserves found in anticline traps are from the coal and coaly shale sourced reservoirs of the Miocene-Coaly Strata TPS, $28 \%$ of the fault-block and faulted traps, and 2\% of the stratigraphic traps (Petroconsultants, 1996).

\section{RESERVOIR ROCKS}

Depositional facies and burial diagenesis influence the reservoir quality in the Malay Basin. Oligocene and Early Miocene deposits are represented by mainly clean, medium-grained sandstones, Middle Miocene shallow marine deposits by fine- to medium-grained sandstones with porosity of $10 \%$ to $15 \%$. Late Miocene estuarine deposits are dominated by fine- to very fine-grained and matrix-rich sandstones. Bioturbation, burial compaction, and authigenic clays are the main reasons for porosity reduction. Development of secondary porosity by the dissolution of feldspar is locally important.

Oligocene-Miocene Lacustrine Total Petroleum System

The oldest producing reservoir rocks are upper Oligocene, M and L group, fluvial sandstones (Fig. 3) (Ngah, and others, 1996, Tjia and Liew, 1996, and Tjia 1994). These 
are generally coarse- to medium-grained sandstones with porosity of $10 \%$ to $27 \%$ and permeability averaging $400 \mathrm{mD}$ (Petroconsultants, 1996). These groups account for approximately $6 \%$ of the discovered estimated recoverable reserves of oil, gas, and condensate from lacustrine sources in the province (Petroconsultants, 1996, McCaffrey and others, 1998, Creaney and others, 1994).

The K Group is interpreted to be of late Oligocene to early Miocene age (Ngah, and others, 1996, Tjia and Liew, 1996, and Tjia 1994). The reservoir rocks in this group are mostly fluvial sandstone with porosity of $10-30 \%$ and permeability of up to $3000 \mathrm{mD}$ (Petroconsultants, 1996). There is some secondary porosity development from solution of feldspars at the south end of the basin due to uplift and exposure of the K Group during deposition of the J Group (Chu Yun Shing, 1992). Cements of quartz and authigenic clays are common (Chu Yun Shing, 1992). This group accounts for approximately $16 \%$ of the reserves of oil, gas, and condensate from lacustrine sources (Petroconsultants, 1996, McCaffrey and others, 1998, Creaney and others, 1994). Production from the Bongkot Field in Thai waters is from Malay II/III fluvial channel sandstones (Leo, 1997). These K Group equivalents were deposited by a large delta prograding from the north. These strata sometimes directly overlie Oligocene lacustrine shales (Leo, 1997).

The overlying J Group reservoirs consist of fluvial and shoreline deposited sandstones of early Miocene age (Nik Ramli, 1986; Ngah, and others, 1996, Tjia and Liew, 1996; Tjia 1994). The J sandstone studied by Nik Ramli (1986), in a location in the southeast Malay Basin, consists of shoreface barred wave- and storm-dominated and offshore stacked bars. It is equivalent to the lower Arang Formation in West Natuna, 
Tapis Formation of the Trenggann Group in South Malay and West Natuna, and the lower member of the Sand-coal Formation of the South Malay-Tenggol Arch area (Nik Ramli, 1986; Ngah, 1996). These bioturbated sandstones are quartzose, with some sedimentary rock fragments. They and are moderately well-sorted, medium-grained sandstones that locally contain gravels (Chu Yun Shing, 1992). Authigenic cements include quartz overgrowths, and kaolinite, illite, chlorite and smectite clays (Chu Yun Shing, 1992). The J Group produces lacustrine sourced oil, gas, and condensate from reservoirs with porosity ranging from $11-30 \%$ and permeability of up to $2000 \mathrm{mD}$ (Petroconsultants, 1996; McCaffrey and others, 1998; Creaney and others, 1994). More than $20 \%$ of the discovered estimated recoverable reserves are assigned to this group (Petroconsultants, 1996).

The lower to upper Miocene E Group was deposited in an estuarine depositional environment (Chu Yun Shing, 1992).

The lower to middle Miocene I Group reservoir rocks are described as shallow marine. This group contains approximately $9 \%$ of the reserves in the province. Reservoir rocks have $25-30 \%$ porosity and up to $1000 \mathrm{mD}$ permeability (Petroconsultants, 1996). The reservoirs contain condensates and oils sourced from a mix of lacustrine and coaly source rocks (McCaffrey and others, 1998). Miocene-Coaly Strata Total Petroleum System

The middle to upper Miocene H to D groups (Fig. 3) contain reservoir rocks of medium- to very fine-grained, shallow marine sandstones. The upper Miocene rocks from the Jerneh field in the northern portion of the Malay Basin include abundant coal beds and marine-influenced deltaic and coastal plain sandstones and glauconitic 
sandstones. These sandstones are interpreted to have been deposited in mangrove swamps and tidal channels (Mazlan B. Hj. Madon, 1994). These reservoirs have up to $30 \%$ porosity, $1000 \mathrm{mD}$ permeability, and contain approximately $38 \%$ of the reserves of the province (Petroconsultants, 96). These reservoirs produce predominately condensate and gas that is derived from coaly source rocks.

\section{SEAL ROCKS}

There are effective local and regional shale seals in the Malay Basin as well as sealing faults. Intraformational seals of overbank and transgressive shales seal individual channel sandstones and marine shales encase some nearshore marine sandstones (Ramli, 1986). The regional marine shale associated with a maximum flooding surface between groups I and H seals reservoirs older than I and may separate the two petroleum systems (Fig. 3) (McCaffrey and others, 1998; Tjia and Liew, 1996). Transgressive marine shales in the Miocene-Coaly Strata TPS, like the one between groups H and F, are also effective seals where present primarily in the eastern part of the basin (McCaffrey and others, 1998).

\section{UNDISCOVERED PETROLEUM}

Undiscovered resources could be found in the Oligocene-Miocene Lacustrine TPS by drilling specific locally derived syn-rift deposits of alluvial and fluvial origin. These strata might be involved in inversion. Late rift strata of deltaic and less locally derived fluvial systems that overly the half graben basins are productive reservoirs in other provinces in the Asia Pacific region (Bishop, 2000). Particular attention to these 
prospects in the Khmer Trough area could yield several large discoveries similar to those of the Sunda and Asri basins in northwest Java (Bishop, 2000). There might also be a possibility of basin-centered-gas in the deeply buried central portions of the Malay Basin where lacustrine source rocks are overmature.

There may be numerous additional discoveries in fluvial channel and shoreline to shallow marine sandstones of the Miocene-Coaly Strata TPS since these discrete sandstones can be difficult to locate and image. These reservoirs are primarily in structural traps but stratigraphic traps could be attractive exploration targets. Low-stand valley-fill deposits and clastic delta and submarine fan systems sourced by highs to the north, southwest, and east are possibly unrecognized prospects.

\section{REFERENCES CITED}

Ahmad Said, 1982, Overview of exploration for petroleum in Malaysia under the production-sharing contracts: Offshore Southeast Asia 82 Conference, p 1Akihiko Okui, Akinori Imayoshi, and Kohsuke Tsuji, 1997, Petroleum system in the Khmer Trough, Cambodia: Proceedings of the Indonesian Petroleum Association, p.365-379.

Bishop, M. G., 2000, Petroleum systems of the Northwest Java Province, Java and offshore southeast Sumatra, Indonesia: U. S. Geological Survey Open File Report 99-50R.

Chu Yun Shing, 1992, Petrographic and diagenetic studies of the reservoir sandstone of the Malay Basin: Geol. Soc. Malaysia, Bull. 32, p. 261-283. 
Cole, J. M., and Crittenden, S., 1997, Early Tertiary basin formation and the development of lacustrine and quasi-lacustrine/marine source rocks on the Sunda Shelf of SE Asia; in Fraser, A. J. Matthews, S. J. and Murphy, R. W. eds., Petroleum Geology of Southeast Asia: Geological Society Special Publication, No. 126, pp. 147-183.

Cooper, M. A., Williams, G. D., de Graciansky, P. C., Murphy, R. W., Needham, T., de Paor, D., Stoneley, R., Todd, S. P., Turner, J. P., and Ziegler, P. A., 1989, Inversion tectonics—a discussion; in Cooper, M. A., and Williams, G. D., eds., Inversion Tectonics: Geological Society Special Publication, No. 44, pp. 335-347. Creaney, S., Hussein Abdul Hanif, Curry, D. J., Bohacs, K. M., and Hassan Redzuan, 1994, Source facies and oil families of the Malay Basin, Malaysia: AAPG Bull., 78, p.1139.

Du Bois, E. P., 1980, Synoptic review of some hydrocarbon-bearing and potentially hydrocarbon-bearing basins of southeast Asia: Proceedings of the seventeenth session of the committee for co-ordination of joint prospecting for mineral resources in Asian offshore areas (CCOP), Bangkok, Thailand, p. 245-285.

Hutchison, C. S., 1996, South-East Asian Oil, Gas, Coal and Mineral Deposits: Oxford Monographs on Geology and Geophysics, 36: Clarendon Press, Oxford, 265 p.

Leo, Coen T. A., 1997, Exploration in the Gulf of Thailand in deltaic reservoirs, related to the Bongkot Field; in Fraser, A. J., Matthews, S. J., and Murphy, R. W., eds., Petroleum Geology of Southeast Asia: Geological Society Special Pub., no. 126, p 77-87.

Liew Kit Kong, 1994, Structural development at the west-central margin of the Malay Basin: Geol. Soc. Malaysia, Bull. 36, p. 67-80. 
MacGregor, D. S., 1995, Hydrocarbon habitat and classification of inverted rift basins; in Buchanan, J. G., and Buchanan, P. G., eds., Basin Inversion: Geological Society Special Publication No. 88, p 83-93.

Mazlan B. Hj. Madon, 1994, Depositional and diagenetic histories of reservoir sandstones in the Jerneh field, central Malay Basin: Geol. Soc. Malaysia, Bull. 36, p. $31-53$.

Mazlan B. Hj. Madon, 1997, The kinematics of extension and inversion in the Malay Basin, offshore peninsular Malaysia: Geol. Soc. Malaysia, Bull. 41, p. 127-138. McCaffrey, M. A., Abolins, P., Hoesni, M. J., and Huizinga, B. J., 1998, Geochemical characterisation of Malay Basin oils: some insight into the effective petroleum systems; GEOSEA '98: Geological Society of Malaysia, program and abstracts, p. 149.

Mohd Firdaus Abdul Halim, 1994 Geothermics of the Malaysian sedimentary basins: Geol. Soc. Malaysia, Bull. 36, p. 163-174.

Ng Tong San, 1987, Trap styles of the Tenggol Arch and the southern part of the Malay Basin: Geol. Soc. Malaysia Bulletin 21, December 1987, p. 177-193.

Ngah, K., Mazlan Madon and Tjia, H. D., 1996, Role of pre-Tertiary fractures in formation and development of the Malay and Penyu basins; in Hall, R. and Blundell, D., eds., Tectonic Evolution of Southeast Asia: Geol. Soc. Special Pub. No. 106 , p. 281-289.

Nik Ramli, 1986, Depositional model of a Miocene barred wave-and storm-dominated shoreface and shelf, southeastern Malay Basin, offshore west Malaysia: AAPG Bull. V. 70, No. 1, p. 34-47. 
Oil and Gas Journal, 1998, Cambodia: Idemitsu releases Block 3, December 1, 1998, V. 58, issue 12 , O\&Gjournalonline.com.

Petroconsultants, 1996, Petroleum Exploration and Production Database: Petroconsultants, Inc., P.O. Box 740619, 6600 Sands Point Drive, Houston TX 77274-0619, USA or Petroconsultants, Inc., P.O. Box 152, 24 Chemin de la Mairie, 1258 Perly, Geneva, Robinson, K., 1985, Assessment of undiscovered conventionally recoverable petroleum resources in Tertiary sedimentary basins of Malaysia and Brunei: Geol. Soc. Malaysia, Bull. 18, p. 119-131.

ten Haven, H. L., and Schiefelbein, C., 1995, The petroleum systems of Indonesia: Proceedings, Indonesian Petroleum Association Twenty Fourth Annual Convention, October, 1995, p. 443-459.

Tjia, H. D., 1994, Inversion tectonics in the Malay Basin: evidence and timing of events: Geol. Soc. Malaysia, Bull. 36, p. 119-126.

Tjia, H. D., and Liew, K. K., 1996, Changes in tectonic stress field in northern Sunda Shelf basins; in Hall, R. and Blundell, D., eds., Tectonic Evolution of Southeast Asia: Geol. Soc. Special Pub. No. 106, p. 291-306.

Todd, S. P., Dunn, M. E., and Barwise, A. J. G., 1997, Characterizing petroleum charge systems in the Tertiary of SE Asia, in Fraser, A. J. Matthews, S. J. and Murphy, R. W. eds., Petroleum Geology of Southeast Asia: Geological Society Special Publication, No, 126, pp. 25-47.

U. S. Geological Survey World Energy Assessment Team, 2000, U. S. Geological Survey World Energy Petroleum Assessment 2000-Description and Results: USGS Digital Data Series DDS-60, four CD-ROMs. 


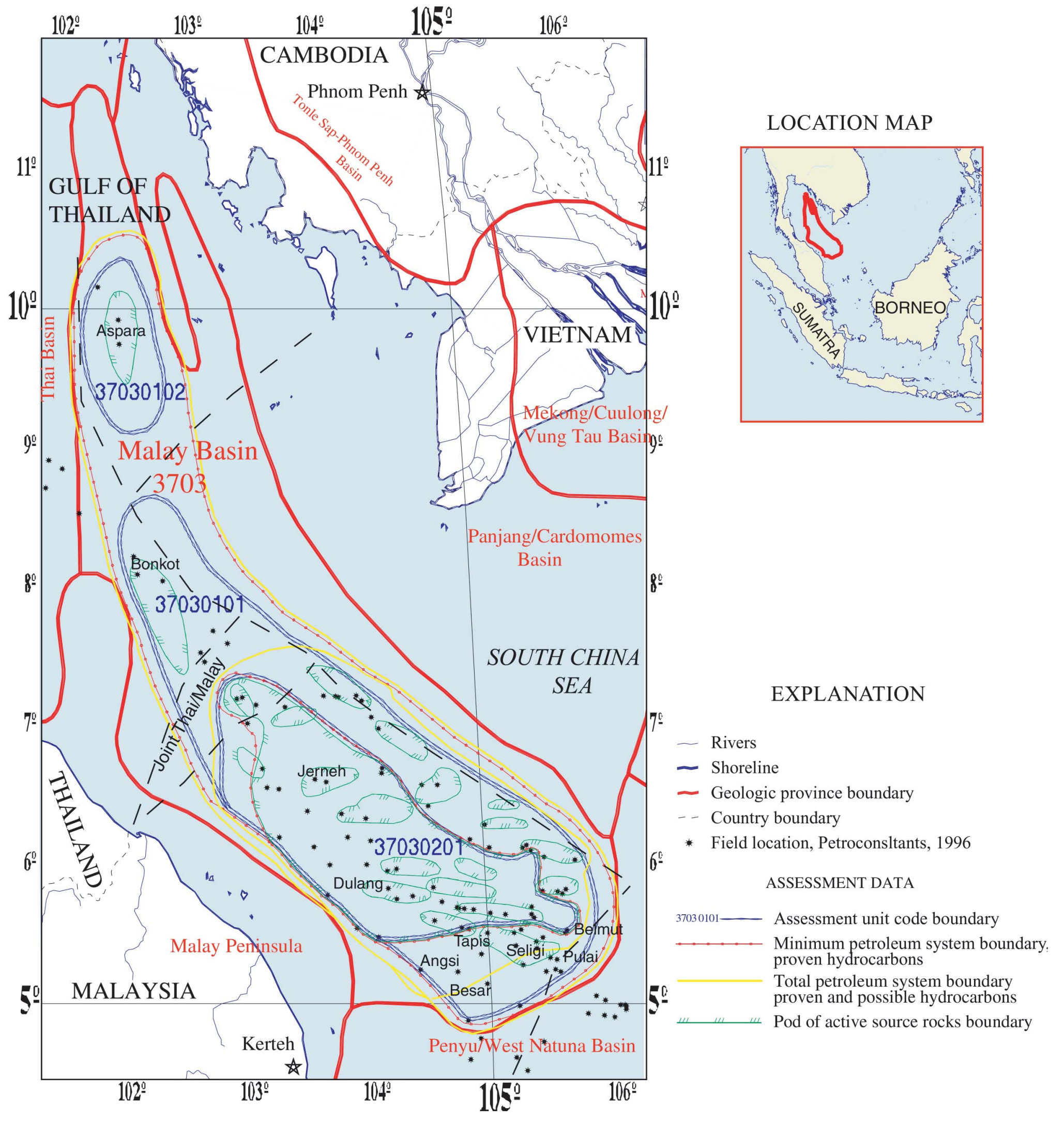

Figure 1. Index map of Malay Basin Province, Malaysia (3703). Two petroleum systems are shown. The Oligocene-Miocene Lacustrine Total Petroleum System (370301) is sourced by lacustrine rocks and has two assessment units, South Malay Lacustrine (37030101) and North Malay Laucstrine (37030102). The Miocene-Coaly Strata Total Pelroleum System (370302) is sourced by coal and coaly shale rocks and has one assessment unit, South Malay Coal (37030201). 


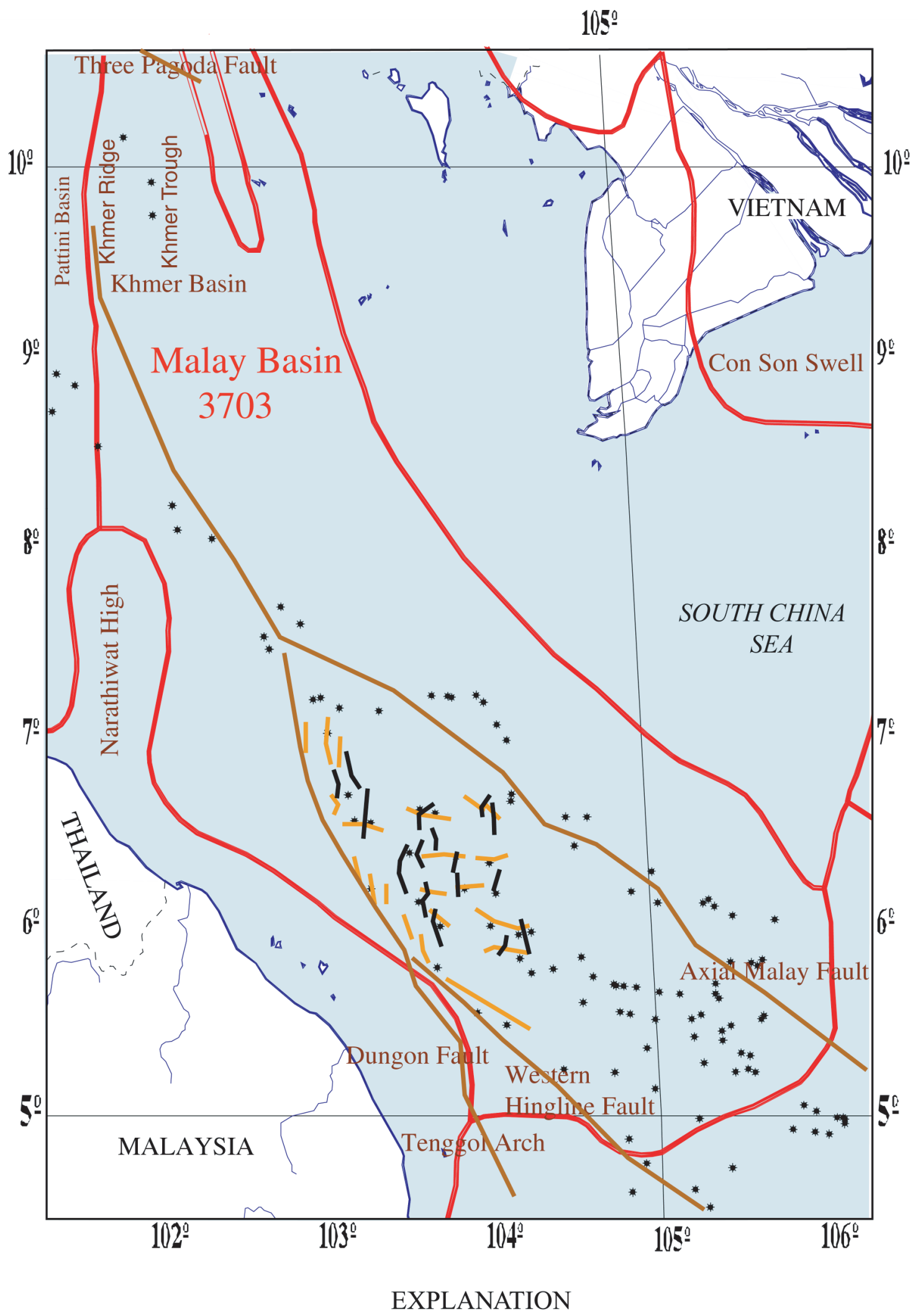

- River

— Shoreline

- Geologic province code and boundary

- Country boundary
* Field location, Petroconsultants, 1996

- Normal fault

- Strike slip fault

- Anticline

Figure 2. Simplified structure of the Malay Basin province (3703). Compiled from Ngah and others, 1996; Tjia and Liew, 1996. 




Figure 3. Simplified comparisons of stratigraphy from different areas in the Malay Basin province. Combined from McCaffrey and others, 1998; Tjia and Liew, 1996; Tjia, 1994; Ngah and others, 1996; Akihiko and others, 1997: Hutchison, 1996. 


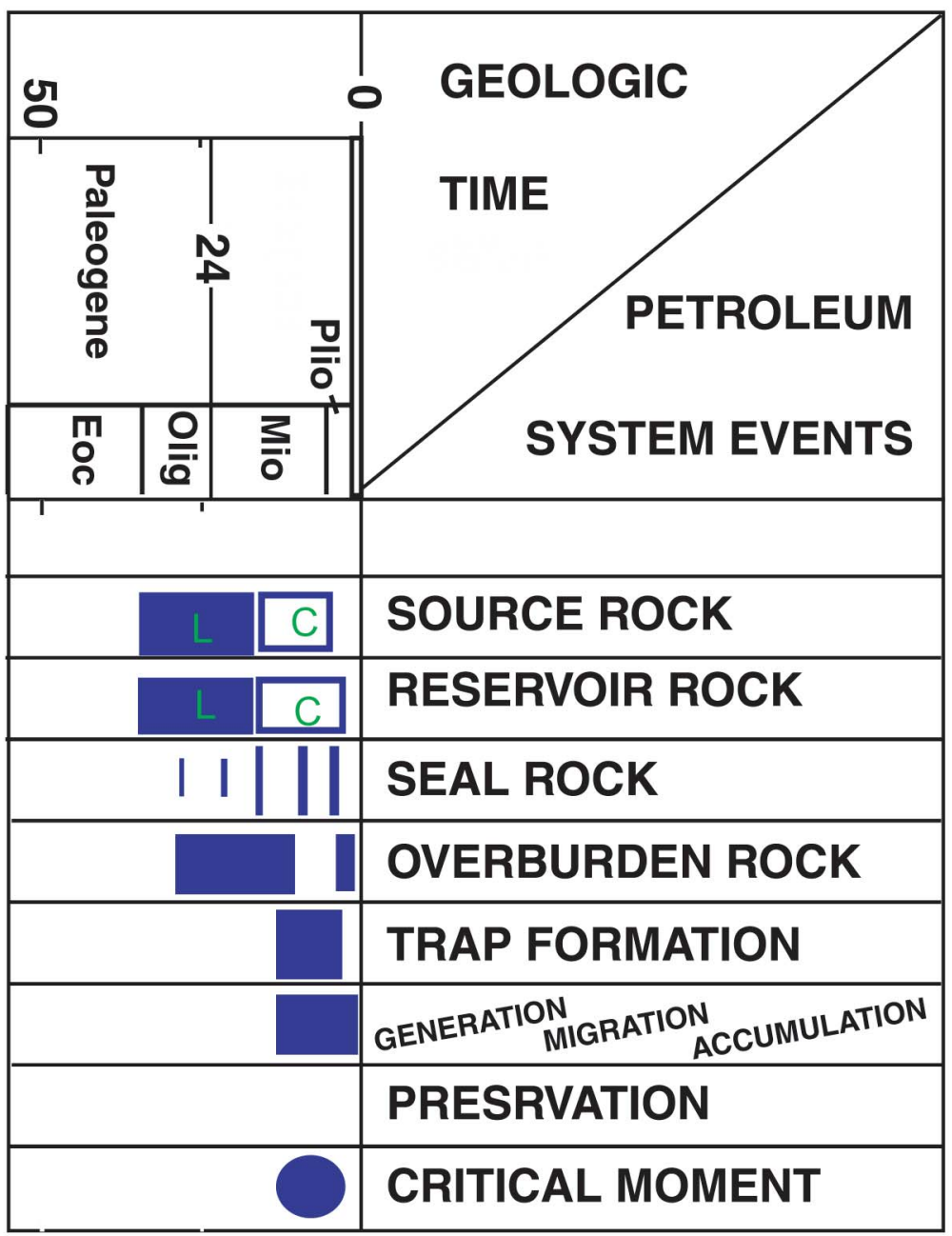

Figure 4. Events chart for the Malay Basin Province 3703. Shown are the lacustrine (L) Oligocene-Miocene Lacustrine Total Petroleum System and the Miocene-Coaly Strata (C) Total Petroleum System. 